\title{
INCREASING RESOURCE OF SCRAPER CONVEYORS
}

\author{
Hlushkova D.B., Voronova E.M., Demchenko S.V. \\ Kharkiv National Automobile and Highway University
}

\begin{abstract}
We have studied the properties of steels BRK, 18ChGT, 20ChGNB used for the manufacture of sidewalls of chute conveyor pans after various treatment regimes in order to select the most appropriate one. The working conditions stipulate high demands to chute conveyor pan material with respect to strength and durability, and the term of chute conveyor pan service is determined by the sidewall stability. The level of properties, microstructure of sidewalls after thermal treatment as well as the heat treatment and welding are analyzed. As between the hardness and wear resistance there is a direct relationship, the research methodology consisted in measuring the hardness, strength indicators, and study of the microstructure. It was revealed that after the heat treatment and welding of pan sidewalls made of steel BRK there is not provided the desired level of strength (the tensile strength must not be lower than $1275 \mathrm{MPa}$ ), and there is observed unevenness in the distribution of hardness and strength properties over the cross section. This can be avoided using alloy steels. It was established that the profiles made of steel 20ChGNB when quenched in oil provide a higher level of properties than profiles made of steel 18ChGT. When welding the sidewalls of pans made of steel 20ChGNB with other parts of pans subject to wear the softening areas do not exceed 2-3 HRC. On the basis of the above studies it should be noted that steel 20ChGNB can be recommended for the manufacture of sidewalls of pans.
\end{abstract}

Key words: steel, pan sidewall, hardness, strength, wear resistance, welding, hardening, cross section, microstructure.

\section{Introduction}

Premature destruction of chute conveyor pans leads to reduction in coal production and creates conditions for the emergence of accidents.

Studies of worn surface of pans showed that chutes, and in particular, the sidewalls during operation are subjected to abrasion. The hardness of the material determines the value of mutual implementation of microscopic irregularities of the rubbing surfaces. The authors of papers [1,2] have established the relationship between the hardness and wear resistance of the test material. The operating conditions set high demands to the material the pans are made of in respect of strength and durability.

Currently the chutes are made of steel BRK, which is supplied from the metallurgical plant «Azovstal». Statistics show that the duration of operation of pans SP-87P, and KM-81-025M is
6-9 months and during that time the transportation of only 300-400 tons of coal at a rate of 650 thousand tones is provided. In this case, basically, the term of pan service is defined by the resistance of the sidewall.

\section{Formulation of the problem}

In connection with the above, the objective of the present study was the choice of material for sidewalls of pans by comparing the properties of the applied and proposed grades of steel. For this purpose, the level of properties, microstructure of sidewalls after the heat treatment, heat treatment and welding (it is the order the technological operations are performed in the manufacture of pans) is subject to analysis.

Steel BRK and steel 18ChGT and 20ChGNB, the chemical composition of which is shown in Table, were used as the material of the given study.

Table - Chemical composition of investigated steel

\begin{tabular}{|c|c|c|c|c|c|c|c|c|c|}
\hline \multirow{2}{*}{$\begin{array}{c}\text { Grade of } \\
\text { steel }\end{array}$} & \multicolumn{9}{|c|}{ Composition of elements, \% } \\
\cline { 2 - 11 } & $\mathrm{C}$ & $\mathrm{Mn}$ & $\mathrm{Si}$ & $\mathrm{Cr}$ & $\mathrm{Ni}$ & $\mathrm{Ti}$ & $\mathrm{B}$ & $\mathrm{S}$ & $\mathrm{P}$ \\
\hline Steel BRK & 0,29 & 0,97 & 0,20 & - & - & - & - & 0,027 & 0,027 \\
\hline $\begin{array}{c}\text { Steel } \\
\text { 18ChGT }\end{array}$ & 0,18 & 0,97 & 0,30 & 1,25 & 0,17 & 0,050 & - & 0,019 & 0,022 \\
\hline $\begin{array}{c}\text { Steel 20 } \\
\text { ChGNB }\end{array}$ & 0,20 & 0,79 & 0,30 & 1,05 & 1,02 & - & 0,005 & 0,018 & 0,021 \\
\hline
\end{tabular}

(Developed by the authors) 
The methodology of the study was to measure the hardness, strength indicators, and investigate the microstructure. As between the hardness and wear resistance there is direct relationship, according to hardness indicators there can be estimated the performance characteristics of sidewalls of pans.

\section{Results obtained and discussion}

The results of study of steel BRK showed that in the hot-rolled state (before heat treatment) the hardness values distribution across the perimeter and the cross section of the profile is about $15 \mathrm{HB}$, and the ultimate tensile strength and the yield strength respectively 27 and $36 \mathrm{MPa}$. The microstructure of steel is ferritepearlite.

After heat treatment, including quenching from $850-870{ }^{\circ} \mathrm{C}$ in water and tempering at $200{ }^{\circ} \mathrm{C}$, the sidewalls pans made of steel BRK, there is observed a considerable distribution of hardness across the cross section of the profile, cut from the pan of current production (Fig. 1). Thus, at the edges of the minor and major flanges, the thickness of which is 9 to $12 \mathrm{~mm}$, the hardness is respectively $444-777$ and 320 $340 \mathrm{NV}$. In areas of transition of minor and major flanges into the profile wall, wherein the thickness increases by approximately 2 times, the hardness is respectively reduced to $217 \ldots$ 223 HB (Fig. 1, a).

An even greater decrease in hardness is observed with increasing the distance from the edge of the profile (in length). So, at a distance of $300 \mathrm{~mm}$ from the edge (the distance the specified hardness should be provided at), the latter is slightly different from the hardness of hot-rolled profiles and is only 166-217 HB (Fig. 1, b).

The obtained after appropriate heat treatment in laboratory conditions results of mechanical properties measurement indicate that on steel BRK after quenching and tempering at the temperature of 200 and $400{ }^{\circ} \mathrm{C}$ there not provided both the required absolute values and the uniform distribution of strength properties of hardness and the uniformity of the microstructure along the cross section of the profile.

If, after quenching and low tempering the temporary resistance to the tensile strength constitutes 765-1040 MPa (range of strength values is $275 \mathrm{MPa}$ ), then after tempering at the temperature of $400{ }^{\circ} \mathrm{C}$, the level of tensile strength decreases mainly due to the reduction of the upper limit of 706-905 MPa ( distribution of strength values is equal to $199 \mathrm{MPa}$ ).

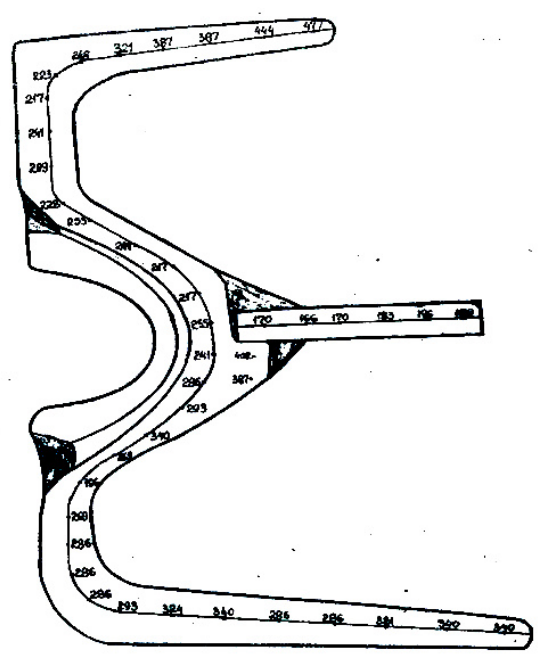

$\mathrm{a}$

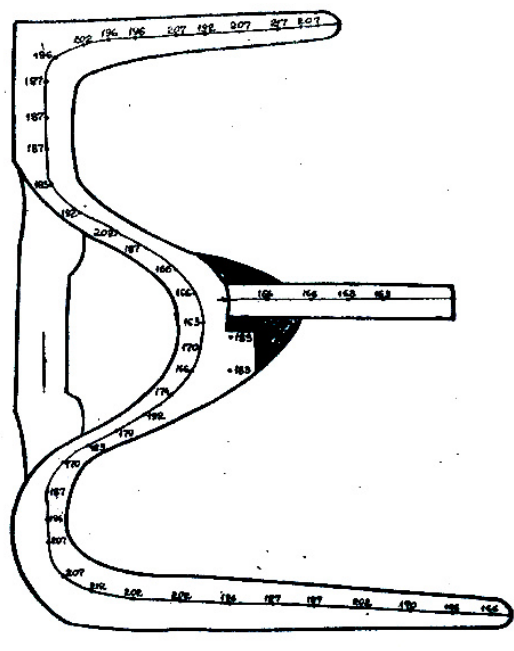

b

Fig. 1. Hardness (HB) in the cross section of templates of sidewalls of the pan made of steel BRK, cut from the pan of current production: $\mathrm{a}$ - profile edge; $\mathrm{b}$ - at a distance of $300 \mathrm{~mm}$ from the edge (developed by the authors)

Similarly, the yield strength changes as well. The level of the temporary tensile strength values is less than the desired one. It is necessary that the tensile strength should not be less than $1275 \mathrm{MPa}$.

A solid plank is welded (from the broken surface) to the middle part of the profile. The study showed that the heating temperature of the sidewall portion of pan, located closest to the welding point, is $300{ }^{\circ} \mathrm{C}$. On the same section the metal in the middle (trough-the-thickness) of the profile is heated to about $330^{\circ} \mathrm{C}$, and on the surface, somewhat farther from the weld zone, to $250{ }^{\circ} \mathrm{C}$.

The minimum heating temperature is observed on the shelf and it constitutes $120^{\circ} \mathrm{C}$. 
Comparison of the mechanical properties and microstructure of profiles after machining, including quenching and tempering at $400{ }^{\circ} \mathrm{C}$ as well as heat treatment and welding revealed that heating of metal during the welding process does not significantly affect the level of hardness, the strength properties of steel and its microstructure.

However, after welding as well as after heat treatment in the cross section and along the length there is observed a large spread in values of properties.

As a consequence, the profile of the pan sidewall has low durability in operation. The reason for this phenomenon is the low hardenability of steel. So, it is necessary to use steel to obtain higher hardenability, which is achieved by the introduction of alloying elements, which shift the chart of isothermal decomposition of austenite right wardsand reduce the critical quenching rate.

Thus, there were carried out studies on the sidewalls of pans, made of steel 18ChGT and 20ChGNB. In the hot rolled state the structure of steel 18HGT is ferrite-pearlite and that of steel 20ChGNB is bainite and separate parts of ferrite have the form of a torn grid along the grain boundaries.

The temperature rolling mode: at the beginning $1150-1160{ }^{\circ} \mathrm{C}$, at the end of rolling - 970$990{ }^{\circ} \mathrm{C}$, the rolling speed $-2,3 \mathrm{~m} / \mathrm{s}$. Hardness in the hot rolled state of the profile made of steel 20ChGNB is 241-262 HB, and that made of steel $18 \mathrm{ChGT}$ is below 10-20 HB. Given the complexity of the geometric shape of the profile and the possibility of its warpage during heat treatment, there was investigated the level of properties, achieved by quenching in a «soft» medium, namely in oil. Studies were carried out simultaneously under cooling in water after tempering.

Heat treatment significantly changed the level of properties and the microstructure of steel investigated.

In steel 20ChGNB, alloyed with boron, after quenching in oil the temporary resistance to tensile strength is at the level of $1430-1440 \mathrm{MPa}$ and the hardness is 35-39 HRC. Steel 18ChGT is significantly inferior in strength compared to steel 20ChGNB properties after quenching in oil.

The ultimate strength is $1030-1020 \mathrm{MPa}$, the yield strength by $300-350 \mathrm{MPa}$, and the hardness by 7-8 HRC is less than in steel 20ChGNB. After water quenching and tempering at $200{ }^{\circ} \mathrm{C}$ the tensile strength of steel $20 \mathrm{ChGNB}$ equal to
1480-1550 MPa, the hardness is 42-45 HRC, and that of steel $18 \mathrm{ChGT}$ is respectively $1385-$ $1470 \mathrm{MPa}$ and 36-43 HRC.

Fig. 2 shows a histogram of mean values of the ultimate tensile strength of steel BRK, 20ChGNB and $18 \mathrm{ChGT}$ after quenching in water and tempering at $200{ }^{\circ} \mathrm{C}$.

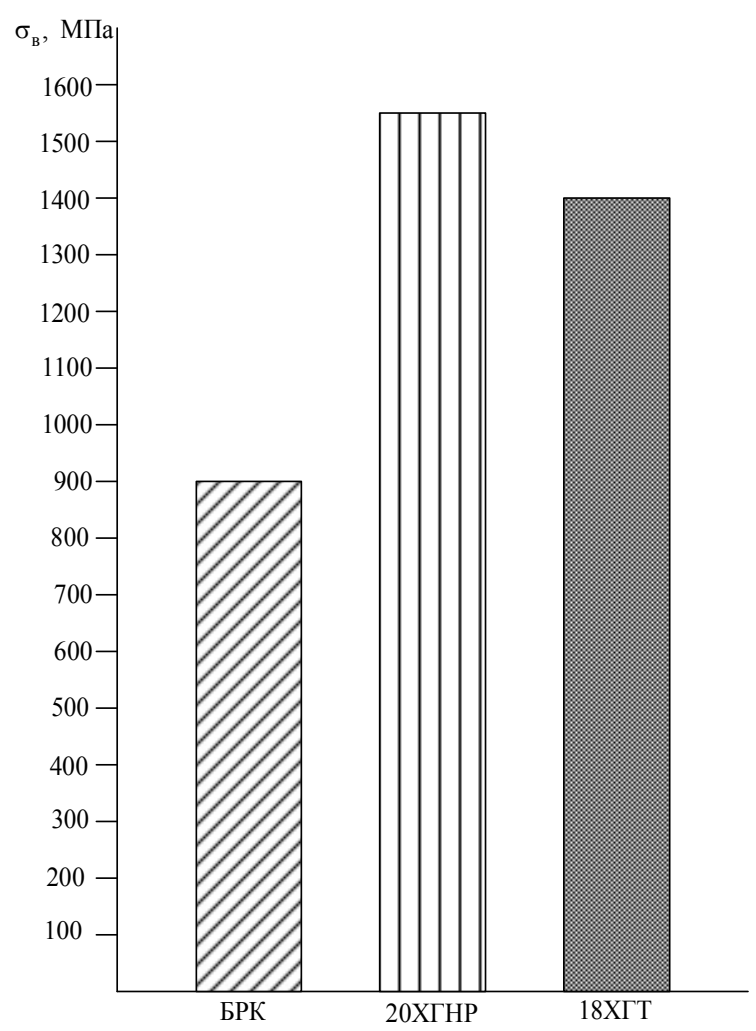

Fig. 2. Histograms of mean values of the tensile strength of steel BRK, 20ChGNB, 18ChGT after quenching in water and tempering at $200{ }^{\circ} \mathrm{C}$ (developed by the authors)

Increasing the tempering temperature to $400{ }^{\circ} \mathrm{C}$ leads to a slight weakening of steel, which does not exceed 5,10\% in relation to the tempered state.

Studies of hardness after quenching, tempering at $300{ }^{\circ} \mathrm{C}$, and welding of the support strap and side walls, bottom and sidewalls showed a slight reduction in hardness compared with a hardened state.

Fig. 3 shows the hardness in the cross section of the pan sidewall made of steel 20ChGNB after heat treatment and welding.

The results obtained indicate that after achieving sufficient hardness after quenching in the cross-section of the profile, subsequent welding of the hardened profile leads to softening of worn areas as a result of operation no more than by $3,2 \%$. 

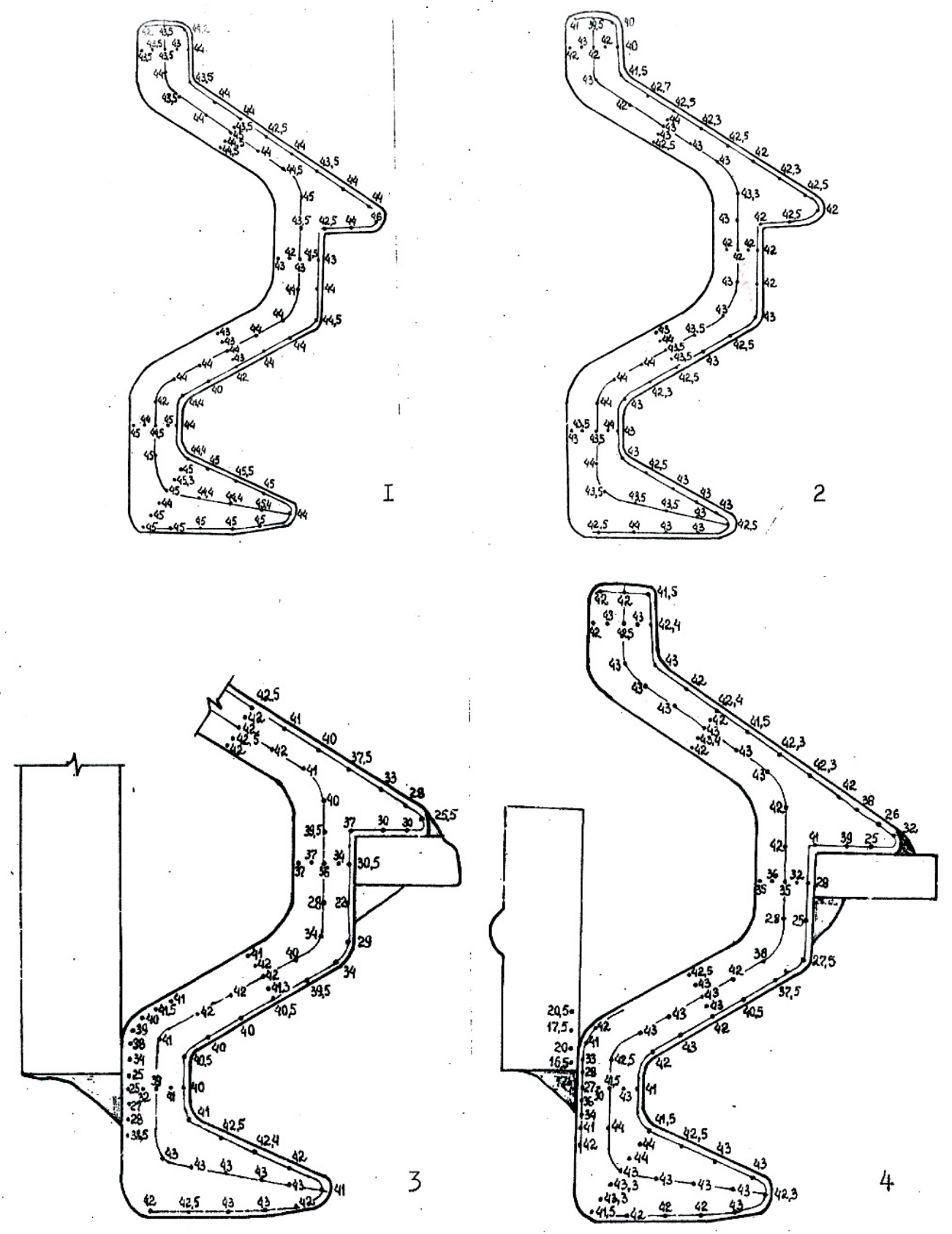

Fig. 3. Hardness (HRC) in the cross-section of the pan sidewall made of steel 20ChGNB after heat treatment and welding: 1 - quenching from $880{ }^{\circ} \mathrm{C} ; 2$ - quenching from $880{ }^{\circ} \mathrm{C}+$ tempering at $300{ }^{\circ} \mathrm{C} ; 3$ - quenching from $880{ }^{\circ} \mathrm{C}+$ welding; 4 - quenching from $880{ }^{\circ} \mathrm{C}+$ tempering at $300{ }^{\circ} \mathrm{C}+$ welding (developed by the authors)

\section{Conclusions}

1. After the heat treatment and welding of the sidewalls of pans made of steel BRK there is not provided the desired level of strength (the tensile strength should not be lower than $1275 \mathrm{MPa}$ ) and there is observed unevenness in the distribution of hardness, strength properties over the cross section.

2. Based on the theoretical positions there is explained a large spread of properties over the cross section and the length of the sidewalls of pans made of steel BRK.
3. Scientifically there was substantiated the application of alloyed steels for the sidewalls of pans.

4. The complexity of the geometric shape of the profile and the possibility of warpage during heat treatment conditions the use of a milder cooling medium at quenching, which is supposed to be oil.

5. Profiles made of steel 20ChGNB at quenching in oil provide a higher level of properties than the profiles made of steel 18 ChGT. 
6. At welding, which is one of fabrication processes of manufacturing the sidewalls of pans, made of steel 20ChGNB, with other parts of pans, softening of sections that are subject to wear does not exceed 2-3 HRC.

7. On the basis of the above studies steel 20ChGNB should be recommended for the manufacture of the sidewalls of pans.

\section{References}

1. Костецкий Б.И. Трение, смазка и износ в машинах. - Киев: Техника, 1970. - 396 с.

2. Абачараев Н.И. Повышение кавитационной стойкости сплошных сред. - Киев: Наукова думка, 1990. - 91 с.

3. Тушинский Л.И. Теория и технология упрочнения металлических сплавов. - Новосибирск: Наука, 1990. - 306 c.

4. Шпеньков Г.П. Физика и химия трения. Минск: БГУ, 1978. -204 с.

5. Проников А.С. Надежность машин. - Москва: Машиностроение, 1978. - 592 с.

6. Тененбаум М.М. Износостойкость конструкционных материалов и деталей машин при абразивном изнашивании. - Москва: Машиностроение, 2006. - $331 \mathrm{c}$.

7. Семенов А.П. Схватывание металлов и методы его предотвращения при трении // Трение и износ. - 1982. - Т. 3. - С. 401-411.

8. Дякин С.И., Филатова Т.П. Некоторые концепции применения материалов в тяжелонагруженных трибосопряжениях // Долговечность трущихся деталей машин: сб. статей / под ред. Д.Н. Гаркунова. - Москва: Машиностроение. - 1987. - Вып. 2. - С. 19-31.

9. Виноградов Г.В. Механизм сухого и граничного трения. - Москва: Машиностроение, 2004. $357 \mathrm{c}$.

10. Файнлейб А.М. Влияние твердости деталей на абразивную износостойкость сопряжения // Металловедение и термическая обработка металлов. - 1997. - № 4. - С. 64-65.

11. Роик Т.А., Глушкова Д.Б., Тарабанова В.П. Влияние химического состава на твердость и износостойкость деталей // Вестник НТУ «ХПИ». - Харьков: НТУ «ХПИ», 2012. № 63. - C. 92-98.

\section{References}

1. Kostetsky B.I. Friction, lubrication and wear in machines. - Kyiv: Technique, 1970. - 396 p.

2. Abacharaev N.I. Increased cavitation resistance of continuous media. - Kyiv: Naukova dumka, 1990. $-91 \mathrm{p}$.

3. Tushinsky L.I. Theory and technology of hardening of metal alloys. - Novosibirsk: Science, 1990. $-306 \mathrm{p}$.

4. Shpenkov G.P. Physics and Chemistry of Friction. - Minsk: BSU, 1978. - $204 \mathrm{p}$.

5. Pronikov A.S. Reliability of machines. - Moskva: Mashinostroenie, 1978. - 592 p.
6. Tenenbaum M.M. Wear resistance of structural materials and machine parts with abrasive wear. Moskva: Mashinostroenie, 2006. - $331 \mathrm{p}$.

7. Semenov A.P. Seizure of metals and methods for its prevention in friction // Friction and wear. 1982. - T. 3. - C. 401-411.

8. Dyakin S.I., Filatov T.P. Some concepts of the use of materials in heavily loaded tribo equipment // Durability of rubbing machine parts: Sat. articles, ed. D.N. Garkunova. - Moskva: Mashinostroenie. - 1987. - Vol. 2. - P. 19-31.

9. Vinogradov G.V. The mechanism of dry and boundary friction. - Moskva: Mashinostroenie, 2004. $-357 \mathrm{p}$.

10. Faynleyb A.M. The influence of the hardness of parts on the abrasive wear resistance of the pairing // Metallography and heat treatment of metals. - 1997. - № 4. - P. 64-65.

11. Roik T.A., Glushkova D. B., Tarabanova V.P. The influence of chemical composition on the hardness and wear resistance of parts // Bulletin of NTU «KPI». - Kharkiv: NTU «KPI», 2012. № 63. - P. 92-98.

Hlushkova D. - Doct. Sc., Chef of Department of Technology of Metals and Materials Science, tel: 057-707-37-29,diana@khadi.kharkov.ua

Voronova E. - PhD, Associate Professor, Department of Foreing Languages, tel:

057-707-37-29, diana@khadi.kharkov.ua

Demchenko S. - Assistant Department of Technology of Metals and Materials Science, tel:

057-707-37-92,diana@khadi.kharkov.ua

Kharkiv National Automobile and Highway University, 25, Yaroslava Mudrogo str., Kharkiv, 61002, Ukraine.

\section{Підвищення ресурсу скребкових конвеєрів}

Анотація. Досліджені властивості сталей BRK, $18 C h G T, 20 C h G N B$, які використовуються для виготовлення боковин рештаків конвеєра після різних режимів оброблення, щэоб вибрати найбільш відповідний. Умови праиі обумовлюють високі вимоги до матеріалу для транспортування жолобів конвеєра щодо міџності та довговічності, а термін служби транспортера жолоба визначається стійкістю боковини. Проаналізовано рівень властивостей, мікроструктуру боковин після термічного оброблення, а також термічне оброблення та зварювання. Оскільки між твердістю та зносостійкістю існує прямий взаємозв'язок, методологія дослідження полягала у вимірюванні показників твердості, міџності та дослідження мікроструктури. Було виявлено, що після термічного оброблення та зварювання боковин рештаків, виготовлених зі сталі БРК, не забезпечується бажаний рівень міџності (міиність на розрив не повинна бути нижчою за 1275 МПа), і спостерігається нерівномірність розподілу твердості та міциі властивості поперечного перерізу. Цього можна уникнути, використовуючи леговані сталі. Установлено, що боковини, 
виготовлені зі сталі 20CHGNB, за умови охолодження в маслі забезпечують більи високий рівень властивостей, ніж боковини зі сталі 18ChGT. У прочесі зварювання боковин із сталі

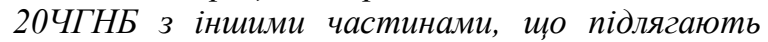
зношуванню, зони пом'якшення не перевищують 2-3 HRC. На підставі проведених досліджень слід зазначити, що сталь 20CGNB може бути рекомендована для виготовлення боковин рештаків.

Ключові слова: сталь, боковини рештаків, твердість, міиність, зносостійкість, зварювання, затвердіння, перетин, мікроструктура.

Глушкова Діана Борисівна - д.т.н., завідувач кафедри технології металів та матеріалознавства, тел.: 097-481-15-93, diana@khadi.kharkov.ua

Воронова Елізавета Михайлівна - доцент кафедри іноземних мов, тел+038-707-37-29, diana@khadi.kharkov.ua

Демченко Сергій Володимирович - ассистент кафедри технології металів та матеріалознавства, тел.: +038-707-37-29, diana@khadi.kharkov.ua Харківський національний автомобільнодорожній університет, 25, вул. Ярослава Мудрого, м. Харків, 61002, Україна.

Повышение ресурса скребковых конвейеров Аннотация. Изучены свойства сталей БРК, 18ХГТ, 20ХГНР, используемых для изготовления боковин рештаков конвейера после различных режсиов обработки, с целью выбора наиболее подходящего. Рабочие условия предъявляют высокие требования к материалу боковин конвейера в отношении прочности и долговечности, а срок службы днища конвейера определяется устойчивостью боковин. Анализируются уровень свойств, микроструктура боковин после термической обработки, а также термическая обработка и сварка. Поскольку между твердостью и износо- стойкостью существует прямая связь, методология исследования состояла в измерении твердости, показателей прочности и изучении микроструктуры. Выявлено, что после термообтермообработки и сварки боковин рештаков из стали БРК не обеспечивается требуемый уровень прочности (предел прочности при растяжении не должен быть ниже 1275 МПа), и наблюдается неравномерность в распределении твердости и прочностные свойства по сечению. Этого можно избежать, используя легированные стали. Установлено, что боковинь из стали 20ХГНР при закалке в масле обеспечивают более высокий уровень свойств, чем профили из стали 18ХГТ. При сварке боковин рештаков из стали 20 ХГНР с другими частями конвейеров, подверженных износу, зоны размягчения не превышают 2-3 HRC. На основании вышеупомянутых исследований следует отметить, что сталь 20ХГНР может быть рекомендована для изготовления боковин рештаков.

Ключевые слова: сталь, боковина рештака, твердость, прочность, износостойкость, сварка, упрочнение, поперечное сечение, микроструктура.

Глушкова Диана Борисовна - д.т.н., заведующий кафедры технологии металлов и материаловедения, тел.: 097-481-15-93,

diana@khadi.kharkov.ua

Воронова Елизавета Михайловна - доцент кафедры иностранных языков, +038-707-37-29, diana@,khadi.kharkov.ua

Демченко Сергей Владимирович - ассистент кафедры технологии металлов и материаловедения, тел.: 097-525-85-13, diana@,khadi.kharkov.ua Харьковский национальный автомобильнодорожный университет, 25, ул. Ярослава Мудрого, г. Харьков, 61002, Украина. 